\title{
Analysis Of Effect of Roadside Parking Space Retribution to Local Own-Source Revenue of Temanggung Regency
}

\author{
Priska Erlyn Oktaningrum ${ }^{1, a^{*}}$; Selfia Bintariningtyas ${ }^{2, a}$ \\ 1priskaerlyn16@gmail.com; 2selfia85@gmail.com
}

aFaculty of Economics and Business, Sebelas Maret University

${ }^{*}$ corresponding author

Article history:

Received : 27-05-2021

Revised : 16-07-2021

Accepted : 18-07-2021

Keywords:

Parking Retribution

Potential

Trend
This study aims to determine (1) The influence of Roadside Parking Space Retribution to Local Own-source Revenue of Temanggung Regency (2) The potential of Roadside Parking Space Retribution of Temanggung Regency on March 2021 (3) The trend of Roadside Parking Space Retribution of Temanggung Regency on March until May 2021 (4) The effectiveness and efficiency ratio of Roadside Parking Space Retribution revenue of Temanggung Regency on 2017 until 2020. This research uses a descriptive quantitative approach. The secondary data was obtained from the Department of Transportation, consisting of the target data for parking retribution, collection fees and the realization of parking retribution that are used in significance test analysis, potential secondary data, trend analysis, effectiveness analysis and efficiency analysis, while the primary data is obtained directly from interviews with parking attendants to calculate the parking potential of primary data. The results of this study are (1) The Roadside Parking Retribution significantly influenced to Local Ownsource Revenue of Temanggung Regency (2) The potential of Roadside Parking Retribution could be developed in order to reach its maximum potential (3) Economic forecasting showed that the next three period downward trend will likely occur (4) The effectiveness ratio of Roadside Parking Retribution revenue categorized as very effective and the efficiency ratio categorized as very efficient. It would be best for Department of Transportation of Temanggung Regency to do an annual survey once a year and to improve awareness on how to use a ticket parking among the people.

This is an open access article under the CC-BY-SA license.

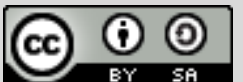

\section{Introduction}

According to Act Number 23 of 2014 On Local Government, it is mentioned that Indonesia adheres to the principles of decentralization, deconcentration, and assistance tasks in running its government by providing opportunities and flexibility to regions to implement regional autonomy. In accordance with Act Number 32 of 2004 On Local Government and Act Number 33 of 2004 on Financial Balance Between Central and Local Governments, Local Governments were given powers to regulate and manage its own 
domestic affairs without much interference from the Central Government. As a result of this handover of authority, the Local Government needs a source of revenue in implementing regional financing which can be obtained from regional revenue; one of which is through Local Own-source Revenue.

Local Own-source Revenue aims to give authority to the Local Government in funding the implementation of regional autonomy as per the potential that the regions have as a manifestation of decentralization. Therefore, Local Own-source Revenue is an indicator of success in implementing regional autonomy. The higher the Local Own-source Revenue of a region, the higher the ability of the Regional Government to finance its own needs, and vice versa. A low Local Own-source Revenue indicates that the level of dependence of the Local Government on the central government is still high, furthermore, it reflects the massive control which the central possesses overall administrative activities of government administration (Devas in Hasita, 2006).

As stated by Hartoyo (2014) to realize the capacity and independence of the regions and strengthen the structure of regional revenues, the role of Local Own-source Revenue must be increased whereas it becomes a measure of regional capacity and a reflection of regional independence. A region that has succeeded in increasing its Local Own-source Revenue significantly indicates that the region has been able to optimally utilize the existing potential (BPS, 2020).

Temanggung Regency is one of the regions that is given the right of regional autonomy and has succeeded in managing its own household affairs, as evidenced by the high revenue from regional levies in 2016 with the highest realization of revenue among the Regencies/Cities included in the former Kedu Residence. The following is the realization of the regional retribution from the Regency/City in the former Second Residential Office.

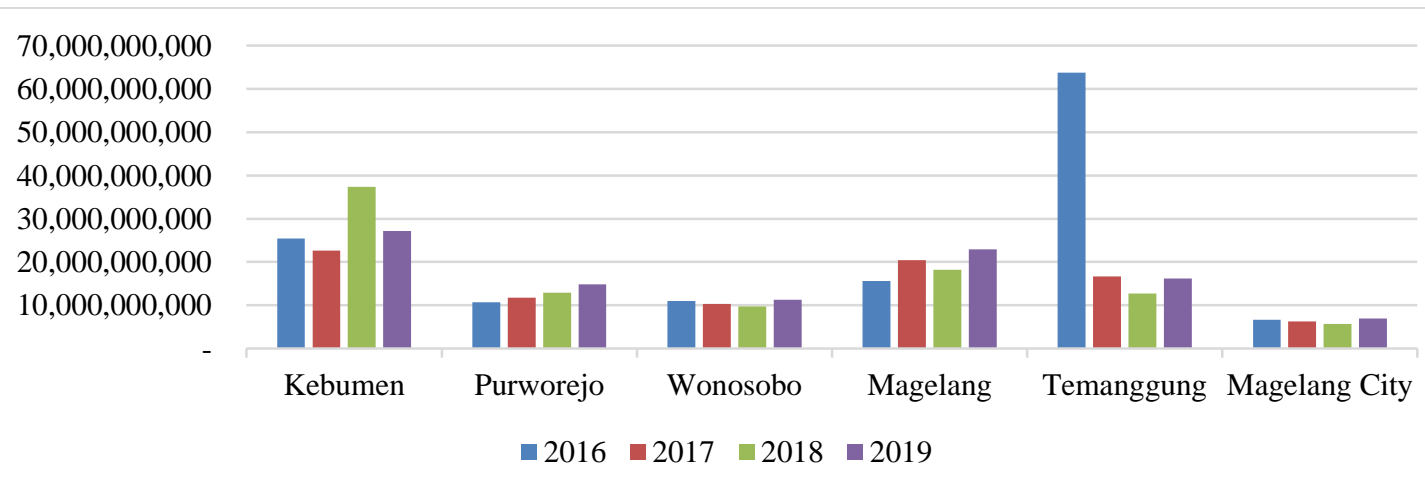

Source: Management of Regional Revenue, Finance and Assets (BPPKAD) of Central Java Province, 2021

Figure 1. Retribution for the Regencies/Cities in the former Kedu Residence 20162019 
In Figure 1 it can be seen that the realization of regional retribution from 2016 to 2019 with the highest revenue reaching more than 60 billion Rupiah was Temanggung Regency, then followed by Kebumen Regency which almost touched 40 billion Rupiah. However, it was unfortunate that in the next two years, regional retribution revenues in Temanggung Regency decreased and then increased again in 2019. Meanwhile, Temanggung Regency Local Own-source Revenue in the last 2 years had increased. The following is the realization of revenue from Temanggung Regency Local Own-source Revenue.

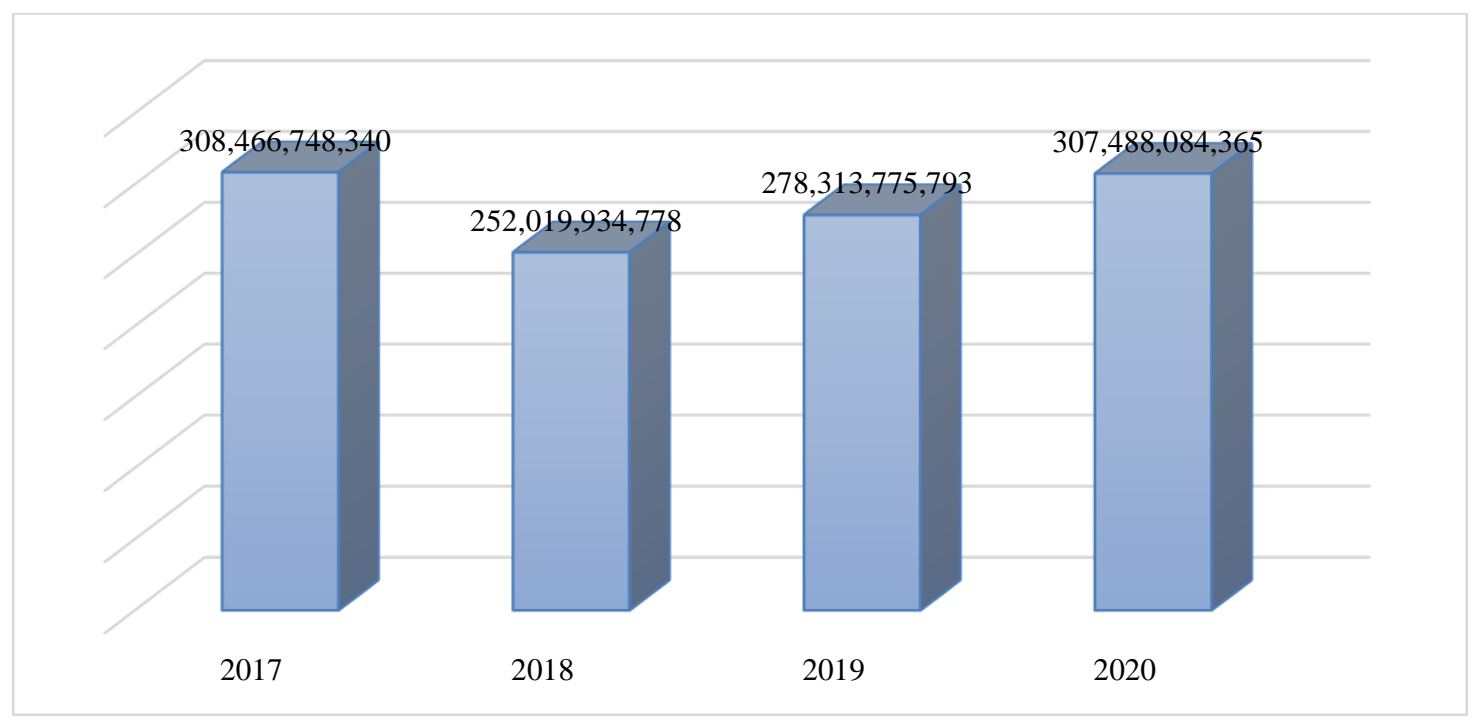

Source: Management of Regional Revenue, Finance and Assets (BPPKAD) Temanggung Regency, 2021

\section{Figure 2. Realization of Temanggung Regency Local Own-source Revenue}

From the figure above, it can be seen that in 2018 the revenue from Temanggung Regency Local Own-Revenue decreased by Rp.56,446,813,562 from the previous year. Thus, in 2019 and 2020, it continued to increase. One alternative retribution that contributes to the Local Own-source Revenue of Temanggung Regency is parking fees. Parking is a potential source of Local Own-source Revenue especially in areas with high levels of vehicle ownership and economic activity, in addition the growth of investment in public and private facilities in districts/cities and provinces supports the provision of new parking spaces that have the potential to contribute to local government revenues (Kartika et al., 2016). The following is the realization revenue of parking retribution in Temanggung Regency.

Table 1. Realization Parking Retribution of Temanggung Regency

\begin{tabular}{ccc}
\hline \multirow{2}{*}{ Year } & \multicolumn{2}{c}{ Parking Retribution Realization } \\
& Specific Parking Spaces (TKP) & Roadside Parking Spaces (TJU) \\
\hline 2017 & $36,147,000$ & $701,193,000$ \\
2018 & $33,579,000$ & $729,927,000$ \\
2019 & $38,066,000$ & $729,830,000$ \\
2020 & $23,492,850$ & $409,990,500$ \\
\hline
\end{tabular}

Source: Department of Transportation of Temanggung Regency, 2021 
From Table 1 it can be seen that each year the realization of the revenue of both parking retribution has fluctuated. The realization of the Specific Parking Spaces (TKP) Retribution in 2018 has decreased from the previous year. Thus, in 2019 it has increased and in the following year it has decreased again. Meanwhile, the realization of Roadside Parking Spaces (TJU) Retribution Revenue in 2018 and 2019 continued to increase from the previous year, then in 2020, the revenue experienced a decline.

In this study, researchers focus on the Public Roadside Parking Retribution. This is because the results of the acceptance of the roadside parking space retribution in Temanggung Regency only come from 9 kecamatan plus 1 kecamatan is still in the trial period, besides that the revenue from the public roadside is greater than the levy for particular parking spaces. The target of receiving the Roadside Parking Spaces Retribution is determined for each provision of parking services on the side of public roads. The amount of target set for the Roadside Parking Spaces Retribution in Temanggung Regency has fluctuated. Main contribution of this study, using the quadratic trend technique to forecast the Roadside Parking Space Retribution of Temanggung Regency for the next 3 periods: March, April, and May 2021. The target and realization of Roadside Parking Spaces Retribution Revenue can be seen in Figure 3.

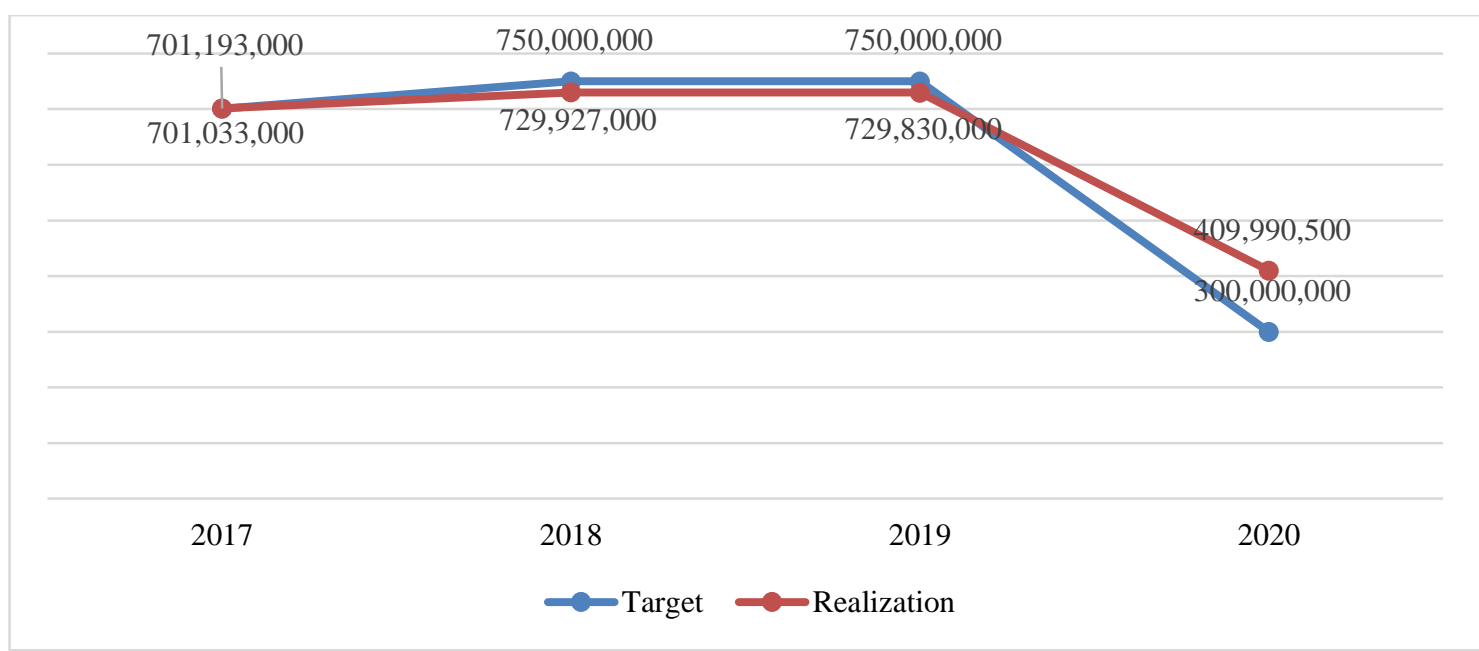

Source: Department of Transportation of Temanggung Regency, 2021

Figure 3. Target and Realization of Roadside Parking Spaces Retribution Revenue in Temanggung Regency 2017 - 2020

From the Figure 3, it can be seen that the target of receiving the Roadside Parking Spaces Retribution in Temanggung Regency in 2018 has increased from the previous year that is Rp.701,033,000 to Rp.750,000,000, wherein 2018 and 2019 the realization of revenue could not reach the target. In 2020, there was a decrease in the target due to the dispensation given to the Covid-19 Pandemic, in which the revenue realization exceeded the predetermined target. 
As in the big cities in Indonesia, vehicles in Temanggung Regency continue to increase every year. Hawati et al. (2017) with their research on The Strategy to Optimize Income for Street Parking Service Retribution in South Tangerang City stated that with increased community economic activity, it will encourage an increase in the number of vehicles resulting in an escalate need for parking space availability so that the parking retribution income will grow.

It is supported by the research in the city of Bandung by Religia \& Pratomo (2014) that taxes and parking retribution have prospects by seeing the increasing number of vehicles in Bandung and vehicles from outside the city. This can bring immense income to the tax sector and parking revenue because the owner of these vehicles requires parking space to park. This is also balanced by the expansion of the parking area; every year the number of factory outlets and distribution stores in the city of Bandung continues to grow. The increase in the number of vehicles in Temanggung Regency can be seen in the image below.

Table 2. The number of vehicles in Temanggung Regency

\begin{tabular}{cccc}
\hline Year & Two-wheeled Vehicles & Four-wheeled Vehicles & Total \\
\hline 2017 & 221,560 & 36,520 & 258,080 \\
2018 & 234,280 & 38,862 & 273,142 \\
2019 & 247,152 & 41,452 & 288,604 \\
2020 & 255,366 & 43,840 & 299,206 \\
\hline
\end{tabular}

Source: Local Revenue Office (Bapenda) of Central Java Province, 2021

This table shows that the number of vehicles in Temanggung Regency from 2017 to 2020 continues to experience a significant increase. The average growth of vehicles from 2017 to 2020 reaching 5.4 percent. The number of two-wheeled vehicles has a higher percentage than four-wheeled vehicles, which is 86 percent in 2017 to 2019 and 2020 by 85 percent. In addition to the number of vehicles, here is the number of parking points for Roadside Parking Spaces Retribution in Temanggung Regency.

Table 3 Parking Point in Temanggung Regency

\begin{tabular}{cccc}
\hline Year & $\begin{array}{c}\text { Number of Parking } \\
\text { Points Handled }\end{array}$ & $\begin{array}{c}\text { Number of Potential } \\
\text { Parking Points }\end{array}$ & $\begin{array}{c}\text { Percentage of } \\
\text { Potential Handled }\end{array}$ \\
\hline 2017 & 101 & 110 & 91.82 \\
2018 & 103 & 110 & 93.64 \\
2019 & 105 & 110 & 95.55 \\
2020 & 107 & 110 & 97.27 \\
\hline
\end{tabular}

Source: Department of Transportation of Temanggung Regency, 2021

The parking points handled by the Department of Transportation of Temanggung Regency as the person in charge of the Roadside Parking Spaces Retribution continue to increase every year by more than 90 percent. Based on previous studies, the income of parking retribution in Temanggung Regency should be able to increase knowing the increased number of vehicles that require parking spots and the increased number of parking points. 


\section{Empirical Study}

Hasan \& Suratman (2013) in a study entitled An Analysis of the Implementation of Parking Management Policies in Increasing the Regional Income of Makassar City, resulted that the contribution of parking retribution to local revenue in 2007-2011 was relatively insignificant which is 0.5 percent, while the contribution of parking taxes showed a significant amount higher up to 1.26 percent. The parking tax contribution which is higher than the levy is due to the tax being imposed every month or year. Furthermore, the object of parking tax is focused on non-individual companies, so a minimal deviation is likely to occur.

Jufrizen (2013) in a study entitled Analisis Potensi Penerimaan Retribusi Parkir pada Pusat Perbelanjaan Kota Medan, the result was that the target set was 52.50 percent of the actual capacity and the remaining 48.50 percent was the lost capacity. Realization of parking retribution revenue in Medan City had not been optimal due to ineffective revenue, unorganized revenue officers, and lack of parking services.

Puspitasari \& Rohman (2014) in a study entitled Analisis Efektivitas, Efisiensi dan Kontribusi Pajak Daerah dan Retribusi Daerah Terhadap Peningkatan PAD Kabupaten Blora Tahun 2009-2013, the result is that the Blora Regency Government has not optimized the potential of regional taxes, while local revenue has been able to but still has not been realized properly. The effectiveness of local taxes and local retribution is in the very effective category, while the efficiency of local taxes and local retribution is in the efficient category. The contribution of local taxes and retribution to Local Own-source Revenue (PAD) Blora Regency has fluctuated every year.

Religia \& Pratomo (2014) in a study entitled Analisis Pengaruh Efektivitas Pajak and Retribusi Parkir Terhadap Efektivitas Pendapatan Asli Daerah Kota Bandung Tahun 2011 Sampai 2013, resulting in parking tax revenue exceeding the target set while parking levies did not reach the target. The parking tax effectiveness ratio has a very effective average, while the parking retribution effectiveness ratio has an average of less effective and the effectiveness ratio of Local Own-source Revenue (PAD) has an average of very effective. There is no partial or simultaneous effect of the effectiveness of parking taxes and parking retribution on the effectiveness of Bandung City Local Own-source Revenue (PAD).

Sriparno \& Sari (2015) in a study entitled Analisis Pajak dan Retribusi Daerah Pada Tingkat Efektivitas dan Kemandirian Keuangan Daerah, the result is that the main component in Denpasar City Local Own-source Revenue (PAD) is local taxes with a contribution reaching $72 \%$ annually. The second is local retribution with a contribution of 
$8 \%$ annually. The average level of effectiveness of local government revenue in Denpasar City in 2009-2013 was $121.45 \%$ with very effective criteria, while the ratio of the level of regional financial independence in 2009-2013 was 64\% with very good criteria.

Malombeke (2016) in a study entitled Analisis Potensi dan Efektivitas Pemungutan Pajak Parkir di Kabupaten Minahasa Utara, the result is that the potential acquisition of parking taxes from 2016-2019 has increased annually. The Department of Transportation, Communication and Information Technology of North Minahasa Regency in setting the target for parking tax collection is right where the level of effectiveness of parking tax revenue in North Minahasa Regency varies.

Putra (2016) in a study entitled yang berjudul Efektivitas Penerimaan Retribusi Parkir Pada Dinas Pendapatan Daerah (DISPENDA) Kabupaten Buleleng Periode Tahun 2010-2015, the result is the effectiveness of the charges for parking from year 2010-2015 was already in categories very effective, the obstacles experienced in receipt of retribution parking is the system management control parking not yet optimal and also there are still many parking officers who have not official, and reduce obstacles in receipt of parking retribution can be done by control or operation routinely and control from the community.

(Saad et al., 2017) in a study entitled Arrangement of the Street Parking at the Pomalaa Market of Kolaka Regency, the result is that parking at Pomalaa Market disturbs the smooth flow of traffic. Jalan Ekonomi, which allows parking for vehicles with a parallel configuration and a 30-degree angle on one side of the road, while Jalan Hati, Jalan Gembira, Jalan Konggasa, and Jalan Hati Senang is only used for motorbikes. Parking management at Pomalaa Market has not been optimal and has not met the predetermined target.

(Soejanto et al., 2018) in a study entitled Monte Carlo Simulation of on-Street Parking Retribution Revenue Potential in Sleman Regency Indonesia, it resulted that roadside parking is a potential source of revenue for the government if it is managed better because the simulation indicates that the potential for parking retribution in Sleman Regency is much lower than the government's revenue target.

Saputra \& Safitri (2020) in a study entitled Implementasi Kebijakan Retribusi Parkir di Tepi Jalan Umum Kota Pangkalpinang, the result of this study reveals that the implementation of the on-street parking retribution policy in Pangkalpinang City is maximal yet. Therefore, it is necessary to evaluate the current on-street parking retribution policy in Pangkalpinang City, so that the local revenue from the on-street parking retribution can be optimized. 


\section{Method}

This study examines primary and secondary data obtained by the Department of Transportation, Department of Management of Regional Revenue, Finance and Assets (BPPKAD), and official parking attendants in Temanggung Regency. The calculation of potential primary data is based on information obtained through interviews with parking attendants who are the research samples. Data which had gotten from the Department of Transportation of Temanggung Regency showed that in 2021, there are 196 official parking attendants spread across 9 kecamatan (an administrative division that is a subdivision of a district). In determining the number of samples, the writer uses the Slovin formula. With an alpha of 10 percent, a sample of 66 parking attendants was obtained. Data analysis technique are:

1. Significance Test of Individual Parameters (T-Test)

This test is carried out using alpha $0.05(\mathrm{a}=5 \%)$. Following are the criteria for acceptance or rejection of a hypothesis with the T-test:

a. If the sig value $<\alpha$ or $\mathrm{T}_{\text {count }}>\mathrm{Ttable}$, then $\mathrm{HO}$ is rejected means that there is a significant influence between the independent variable on the dependent variable.

b. If the sig value $>\alpha$ or $\mathrm{T}_{\text {count }}<\mathrm{Ttable}$, then $\mathrm{H} 0$ is accepted means that there is no significant influence between the independent variable on the dependent variable.

2. Potential Analysis

To calculate the potential revenue for parking retribution in Temanggung Regency in 2021, this study refers to Ritonga et al. (2017:85-92). The formula for calculating potential parking retribution is as follows:

$$
P P R=J k x T p \times J h
$$

PPR are the potential parking retribution; Jk is the number of parked vehiles; Tp is the parking rates; and Jh is the number of days.

3. Trend Analysis

The data used is the data on the realization of revenue from the Roadside Parking Spaces Retribution every month. The research stages:

a. Identify the data used to determine the data plot patterns.

b. Next is to perform the Unit Root Test (ADF) to find out whether the data used is stationary or not.

c. Then determine the best forecasting technique by looking at the smallest MAPE, MAD, and MSD values (Erlangga \& Darsyah, 2018). 
d. The final step is to forecast with the best technique by entering the desired number of periods.

4. Effectiveness Analysis

Based on the Local Own-source Revenue effectiveness ratio (Mahmudi, 2019:141), to find out the effectiveness ratio of parking retribution for Temanggung Regency 20172020, it is calculated as follows:

$$
\text { Effectiveness Ratio }=\frac{\text { Realization of Parking Retribution Revenue }}{\text { Parking Retribution Revenue Target }} \times 100 \%
$$

5. Efficiency Analysis

Based on the efficiency ratio of Local Own-source Revenue (Mahmudi, 2019:141), to find out the efficiency ratio of parking retribution for Temanggung Regency in 20172020, it is calculated as follows:

$$
\text { Efficiency Ratio }=\frac{\text { Parking Retribution Revenue Fees }}{\text { Realization of Revenue of Parking Retribution }} \times 100 \%
$$

\section{Result and Discussion}

\section{Significance Test}

In this study, the t significance test was carried out aiming to test whether there is a significant influence between the independent variables (Roadside Parking Space Retribution) on the dependent variable (Local Own-source Revenue) individually (partially) or not. The basis for making decisions is:

H0 : Roadside Parking Space Retribution do not affect Local Own-source Revenue Temanggung Regency.

Ha : Roadside Parking Space Retribution affect Local Own-source Revenue Temanggung Regency.

If the sig value $<\alpha(0.05)$ or $\mathrm{T}_{\text {count }}>$ Ttable, then $\mathrm{HO}$ is rejected and Ha is accepted. Meanwhile, if the sig value $>\alpha(0.05)$ or $\mathrm{T}_{\text {count }}<$ Ttable, then $\mathrm{H} 0$ is accepted and Ha is rejected. Based on Table 4, the results of the T-test analysis are explained as follows:

\begin{tabular}{|c|c|c|c|c|c|c|}
\hline \multirow{2}{*}{\multicolumn{2}{|c|}{ Model }} & \multicolumn{2}{|c|}{ Unstandardized Coefficients } & \multirow{2}{*}{$\begin{array}{c}\text { Standardized } \\
\text { Coefficients } \\
\text { Beta }\end{array}$} & \multirow[t]{2}{*}{$\mathrm{t}$} & \multirow[t]{2}{*}{ Sig. } \\
\hline & & $\mathrm{B}$ & Std. Error & & & \\
\hline & (Constant) & 9.473 & .370 & & 25.572 & .000 \\
\hline & Tepi Jalan Umum & .115 & .049 & .321 & 2.344 & .023 \\
\hline
\end{tabular}

Table 4. T-Test Output

Source: Processed Data, 2021

Based on the output of Table 4, the result shows that the sig t value is 0.023 which is smaller than $\alpha(0.05)$, so the decision is that $\mathrm{H} 0$ is rejected and $\mathrm{Ha}$ is accepted. So it can be 
concluded that the variables of Roadside Parking Space Retribution affect the Local Ownsource Revenue of Temanggung Regency.

\section{Potential Analysis}

In calculating the potential receipt of primary data parking retribution, the authors refer to Ritonga et al. (2017:85-92) by calculating the number of parked vehicles x parking rates $x$ the number of days for each parking attendant sample. From a total of 196 parking attendants in 9 kecamatan, the authors took a sample of 66 parking attendants from 8 kecamatan. Of all the samples, the average per kecamatan was calculated and the lowest average was selected. This average was chosen because in other kecamatan, the number of parked vehicles was more than the lowest number of kecamatan. From the primary data obtained by the author from a direct survey to the parking attendant, then compared using secondary data, namely the target deposit determined by the Department of Transportation of Temanggung Regency to each parking attendant.

Table 5. Comparison Potential of Primary and Secondary Data

\begin{tabular}{|c|c|c|c|c|c|c|}
\hline \multirow{2}{*}{ Number } & \multirow{2}{*}{ Kecamatan } & \multicolumn{2}{|c|}{ Average Per Day } & \multirow{2}{*}{$\begin{array}{l}\text { Average } \\
\text { Revenue }\end{array}$} & \multicolumn{2}{|c|}{$\begin{array}{c}\text { Department Target } \\
\text { Per Day }\end{array}$} \\
\hline & & $\begin{array}{c}\text { Two-wheeled } \\
\text { Vehicles }\end{array}$ & $\begin{array}{c}\text { Four-wheeled } \\
\text { Vehicles }\end{array}$ & & Min & $\operatorname{Max}$ \\
\hline 1 & Candiroto & 10 & 10 & 30,000 & 5,000 & 9,000 \\
\hline 2 & Kaloran & 45 & 15 & 75,000 & 10,000 & 10,000 \\
\hline 3 & Kandangan & 23 & 9 & 41,000 & 5,000 & 10,000 \\
\hline 4 & Kranggan & 26 & 14 & 54,000 & 5,000 & 22,000 \\
\hline 5 & Ngadirejo & 19 & 17 & 52,500 & 5,000 & 12,000 \\
\hline 6 & Parakan & 25 & 15 & 55,000 & 4,000 & 50,000 \\
\hline 7 & Pringsurat & 35 & 12 & 60,000 & 6,000 & 8,000 \\
\hline 8 & Temanggung & 31 & 17 & 65,000 & 3,300 & 45,000 \\
\hline
\end{tabular}

Source: Processed Data, 2021

A kecamatan (an administrative division that is a subdivision of a district) with the smallest average in this study is Kecamatan Candiroto as the sample with the lowest income of Rp30,000 per day. Meanwhile, the target set by the Department of Transportation each day is in the range of at least $\mathrm{Rp} 3,300$ and a maximum of Rp50,000. From a survey of 66 samples, all parking attendants can get at least Rp30,000 a day. When viewed through this comparison, the target amount set by the Department of Transportation is still too small. The average of the finding is the target set has mostly not reached $30 \%$ of daily revenue. In determining the amount of potential target (secondary data) from The Department of Transportation, each parking attendant is not the same. The target is determined based on the crowd level of the number of parked vehicles.

According to the Head of the Parking and Terminal Section of the Department of Transportation Temanggung Regency, it should be in accordance with the stated regulations, the profit-sharing system of the Parking Retribution from the total parking 
attendant's income is 60 percent for parking attendants and 40 percent for the Local Government. However, in the field implementation, the percentage for parking attendants is up to 70 to 75 percent and the remaining 25 to 30 percent for Local Governments.

From the researcher's observations, kecamatan that have great potential related to parking in Temanggung Regency are in Kecamatan Temanggung and Kecamatan Parakan. The list is followed by Kecamatan Kaloran, Kranggan, Pringsurat, and Ngadirejo Districts which have the potential to be improved again. And the third rank is Kecamatan Kandangan and Kecamatan Candiroto. The official parking attendant is showed by having an Identity Card (KTA) which can be obtained by registering as a parking attendant by fulfilling the following requirements, such as:

a. One has to own a parking lot to manage.

b. A parking attendant has to attach a parking approval letter from the shop/business owner in the area.

c. A parking attendant has to attach identification and a photo.

d. Those who applied must comply with existing regulations and sanctions.

To get the identity card, parking attendants do not have to pay. Parking attendants will get attributes for work consisting of a parking uniform/vest, a light stick, and a whistle. A parking identity card is valid for 1 year, which is issued after the parking attendant has paid the previous year's deposit target. For example, currently, in 2021, they must pay off the deposit target in 2020 first. Identity card revocation occurs if within 2-3 months the parking attendant has no news or makes a deposit. The card is signed by the Head of the Department of Transportation and a photo is attached with a hologram stamp. Identity card has a different model and design every year, which aims not to be easily imitated or faked.

Before becoming an official parking attendant, there will be a trial period to set a deposit target. This trial lasts for a year. During this period, the Department of Transportation calculates the potential to be included in the deposit target. When this research was taking place, several parking attendants were still in the trial period, namely:

a. Kecamatan Wonoboyo has 1 parking attendant.

b. Kecamatan Kandangan has 1 parking attendant.

The Department of Transportation of Temanggung Regency did not issue a parking permit or did not agree to the requirements because it was not approved by the existing business owners in the area. It is usually the land to be used was in an area that was not supposed to use for parking. According to Directorate General of Land Transportation Decision Number: 72/Hk.105/DJRD/96 about Pedoman Teknis Penyelenggaraan Fasilitas 
Parkir states that there are several places on the road that are not allowed to stop or park vehicles, namely:

a. 6 meters before and after the designated pedestrian crossing or bicycle crossing places.

b. Along 25 meters before and after a sharp turn with a radius of less than $500 \mathrm{~m}$.

c. Along 50 meters before and after the bridge.

d. Throughout 100 meters before and after the level crossing.

e. As long as 25 meters before and after the intersection.

f. 6 meters long before and after building access.

g. 6 meters before and after the hydrant/fire extinguisher tap or similar water source.

h. As long as it does not cause a traffic jam and cause danger.

Official parking attendants are required to wear the parking attribute with the identity card used while the person is working. In written rules, the identity card cannot be used by anyone other than the person concerned. When conducting a potential survey, the author found the fact that the owner of the identity card was not a parking attendant in the field, which happened in many places. In addition, one identity card parking attendants have 2-3 people who replace to manage parking on the street. Furthermore, the working hours written on the identity card are not exact. It is rare to find parking attendants giving parking tickets to the users of parking services.

The Department of Transportation Temanggung Regency made a contract agreement to strengthen the two parties between the parking attendant and the Department of Transportation as the parking coordinator. This agreement is valid for a year from the date of signing and ends on December 31 of the current year. If the submission process agreement is extended and both parties have reached an agreement, it has to be done no later than 3 months before the expiration date. If something happens to one party, the other party will also be affected. This binding agreement is currently running for two years, wherein previous years it only consisted of one sheet and the trait was not binding. Trend Analysis

The steps in forecasting or forecasting Roadside Parking Space Retribution in Temanggung Regency are first to determine the data pattern by making a data plot. The second step is to perform a unit root test. Then the next step is to determine the best forecasting technique and finally do forecasting. After that, to analyze the time-series data is to plot the data graphically, which can help visually determine the behavior of the data. The data plot can provide an overview of the patterns that affect the data used (Widarjono, 2005). The following are the results of the data plots presented in Figure 4. 


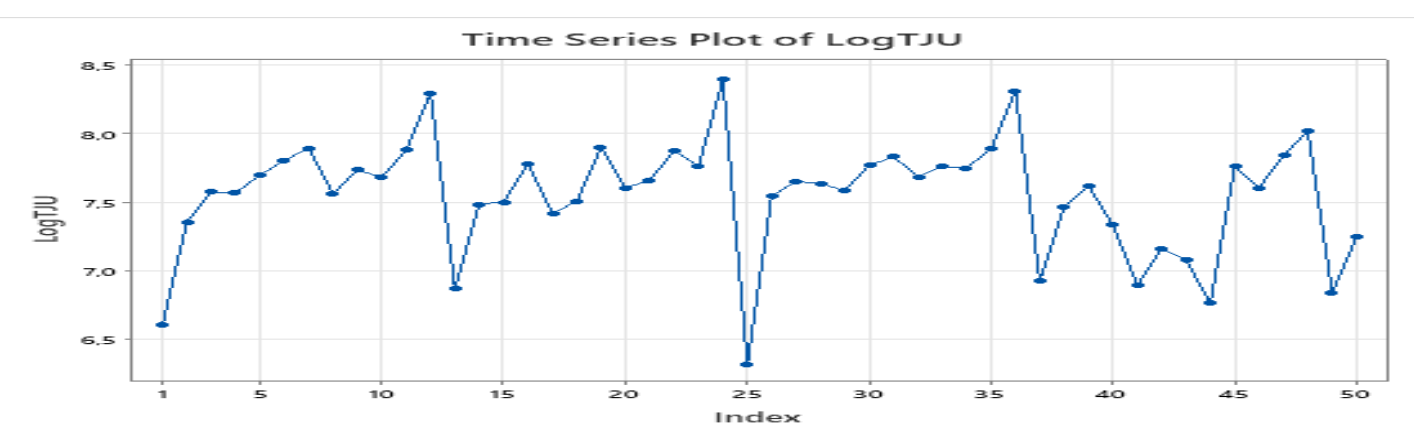

Source: Processed Data, 2021

Figure 4. Data Plot

The data pattern of the Temanggung Regency Roadside Parking Space Retribution is forming an irregular pattern. The data is from January 2017 to February 2021 with a total of 50 months. The second step is to perform the Augmented Dickey-Fuller (ADF) test to determine whether the data used contain unit roots (not stationary) or does not contain unit roots (stationary). In stationary testing, the requirement for a time-series data to be categorized as stationary is if the absolute value of the ADF t-statistic is greater than the absolute value of the t-statistic for MacKinnon's critical value with a predetermined $\alpha$ magnitude (Kurniawan, 2005). The results of the root test output of the Temanggung Regency Roadside Parking Space Retribution using the Eviews11 program are as follows:

Table 6. Augmented Dickey-Fuller Test

\begin{tabular}{lcc}
\hline & t-Statistic & Prob $^{*}$ \\
\hline Augmented Dickey-Fuller test statistic & -7.195653 & 0.0000
\end{tabular}

*Mackinnon (1996) one-sided p-values. Source: Processed Data, 2021

Based on the output of the test results at the level of the stage, it can be seen that the absolute value of the ADF t-statistic is greater than the absolute value of the MacKinnon critical value t-statistic at the level of confidence as Table 6 shown above. So, it can be concluded that the data used for this forecast is stationary or does not contain unit-roots.

Next, is to determine the best forecasting technique which has the smallest MAPE, MAD, and MSD values. Forecasting techniques used in this study are linear trend techniques, quadratic trends, and exponential trends. The output results of each technique are shown in Table 7.

Table 7. MAPE, MAD, and MSD Output

\begin{tabular}{lccc}
\hline \multirow{2}{*}{ Forecasting Technique } & \multicolumn{3}{c}{ Criteria } \\
\cline { 2 - 4 } & MAPE & MAD & MSD \\
\hline Linear & 4.13972 & 0.30460 & 0.16999 \\
Quadratic & 3.91479 & 0.28817 & 0.15944 \\
Exponential & 4.16218 & 0.30678 & 0.17017 \\
\hline
\end{tabular}

Source: Processed Data, 2021 
Based on the table above between the output results in each trend technique, the technique which has the smallest error values is the quadratic technique. Therefore, it can be concluded that the quadratic trend technique is the best forecasting technique to be used in forecasting Roadside Parking Space Retribution Temanggung Regency. The quadratic trend technique is used for forecasting the Roadside Parking Space Retribution of Temanggung Regency for the next 3 periods: March, April, and May 2021. The graphic of the forecasting results is presented in the following figure:

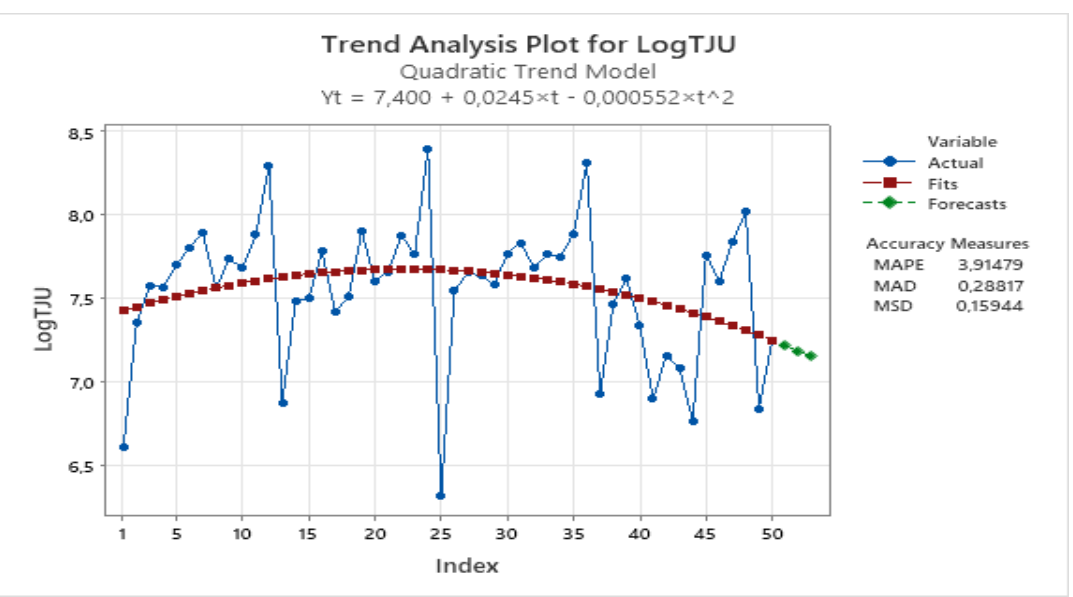

Source: Processed Data, 2021

\section{Figure 5. Forecast}

In Figure 5, indexes 1 to 50 showed the month used in this study with the breakdown of index 1 to 50 (January 2017 - February 2021), which is the data on the realization of parking retribution revenue. Parking retribution revenue often experienced a significant decrease because the parking attendant has to pay arrear deposits over several months. The highest receipt of parking fees occurred in December. This is since parking attendants are required to pay off or pay a deposit in the current year.

Based on the output above, the green variable line showed the results of forecasting the Roadside Parking Space Retribution in Temanggung Regency for the next 3 months (MarchMay). The results of the quadratic trend technique output showed that for the next 3 periods the forecasting results of Roadside Parking Space Retribution in Temanggung Regency showed a downward trend considering the history of previous receipts.

Parking in Temanggung Regency is very dependent on the season. There are off-peak season, mid-season, and peak season. The off-peak season usually occurs from January to March. It is usually near the harvest period. Meanwhile, the peak season is during the tobacco harvest and the fasting month until Eid arrives. This season greatly affects the parking state. Given that people who want to spend their money such as buying new clothes to welcome Eid, they will use parking services to park their vehicles while they are away. If 
the big cities are influenced by weekdays and weekends, it is different in Temanggung Regency considering the average people in Temanggung Regency are farmers; Temanggung is well-known as its slogan "Tobacco City".

\section{Effectiveness Analysis}

The effectiveness of parking revenue is calculated by comparing the realization of parking retribution revenue with the target of receiving parking retribution that has been determined by the Department of Transportation in Temanggung Regency. The results of the calculation of the effectiveness ratio of the Roadside Parking Space Retribution are shown in Table 8.

Table 8. Effectiveness of Roadside Parking Space Retribution 2017-2020

\begin{tabular}{|c|c|c|c|c|}
\hline Year & Realization (Rp) & Target (Rp) & Effectivity (\%) & Criteria* \\
\hline 1 & 2 & 3 & $4=(2 / 3) * 100 \%$ & 5 \\
\hline 2017 & $701,193,000$ & $701,033,000$ & 100.02 & Very Effective \\
\hline 2018 & $729,927,000$ & $750,000,000$ & 97.32 & Effective \\
\hline 2019 & $729,830,000$ & $750,000,000$ & 97.31 & Effective \\
\hline 2020 & $409,990,500$ & $300,000,000$ & 136.66 & Very Effective \\
\hline \multicolumn{3}{|c|}{ Average Level of Effectiveness } & 107.83 & Very Effective \\
\hline
\end{tabular}

Source: Processed Data, 2021

*Decision of Ministry of Home Affairs (Kepmendagri) Number. 690.900 .327 in 1996

From Table 8, it can be seen that in 2017, the Department of Transportation of Temanggung Regency had set a target for Roadside Parking Space Retribution of Rp701,033,000 with a realization of Rp701,193,000 or with an effectiveness ratio of 100.02 percent. This meant that the parking retribution revenue can be categorized as very effective because the ratio exceeded more than 100 percent. In determining the target deposit for each parking attendant, the number of tickets used by the parking attendant does not affect the target set. This is because the targets set by the Department of Transportation are daily. To determine the target amount, a potential survey was carried out when the parking attendant registered to see the level of the crowd at the location.

In 2018 and 2019 there was an increase in the target which was up to Rp750,000,000 with the revenue effectiveness ratio decreasing for 2 consecutive years. It became 97.32 and 97.31 which meant that the receipt of parking retribution is effective. The target that had been set in the previous year, sometimes in the middle of the current year there will obstacles. For example, road construction caused parking attendants to be unable to work in the parking space during the construction process. That way the target in the current year could not be met because parking attendants had difficulty meeting the target set.

In 2020 the target set by the Department of Transportation of Temanggung Regency had changed from Rp800,000,000 to Rp300,000,000. This had been approved by the Executive and Legislative Institutions of Temanggung Regency and the Central Java Province BPK. The 
decrease in the target is due to the impact of the Covid-19 Pandemic related to the policy of reducing the target deposit for parking attendants by providing dispensation or reducing deposits by parking attendants. The amount of dispensation is different in each place whether the place is directly affected by covid or not. Although the Department of Transportation had been giving dispensation to each parking attendant, the realization of the Roadside Parking Space Retribution revenue in that year reached the predetermined target with an effectiveness ratio of 136.66 percent.

From the effectiveness of the Roadside Parking Space Retribution, it can be concluded that the year with the highest effectiveness ratio value is 2020 with a ratio level of 136.66 percent while 2019 is the year with the lowest effectiveness ratio level of 97.31 percent. The effectiveness ratio of Roadside Parking Space Retribution during the last 4 years has an average effectiveness level of 107.83 percent which is included in the very effective category.

\section{Efficiency Analysis}

The efficiency of parking retribution is calculated by comparing the costs incurred by the Department of Transportation Temanggung Regency to obtain parking retribution through the realization of parking retribution. The results of the calculation of the efficiency ratio of the Roadside Parking Space Retribution are shown in Table 9.

Table 9. Efficiency of Roadside Parking Space Retribution 2017-2020

\begin{tabular}{|c|c|c|c|c|}
\hline Year & Realization (Rp) & Target (Rp) & Effectivity (\%) & Criteria* \\
\hline 1 & 2 & 3 & $4=(2 / 3) * 100 \%$ & 5 \\
\hline 2017 & $210,000,000$ & $701,193,000$ & 29.95 & Very Efficient \\
\hline 2018 & $207,000,000$ & $729,927,000$ & 28.46 & Very Efficient \\
\hline 2019 & $223,898,000$ & $729,830,000$ & 30.78 & Very Efficient \\
\hline 2020 & $189,974,800$ & $409,990,500$ & 46.34 & Very Efficient \\
\hline \multicolumn{3}{|c|}{ Average Level of Effectiveness } & 33.83 & Very Efficient \\
\hline
\end{tabular}

Source: Processed Data, 2021

*Decision of Ministry of Home Affairs (Kepmendagri) Number. 690.900.327 in 1996

Based on Table 9, the overall efficiency ratio of theRoadside Parking Space Retribution in Temanggung Regency is included in the very efficient category, which is less than 60 percent. In 2017 and 2018 the efficiency ratio of Roadside Parking Space Retribution Revenue was below 30 percent: two consecutive years of 29.95 percent and 28.46 percent, respectively. Meanwhile, in 2019 and 2020, the efficiency ratios of parking retribution revenue were 30.78 percent and 46.34 percent. During the last four years, the efficiency ratio of Roadside Parking Space Retribution Revenue has an average efficiency level of 33.83 percent which is categorized as very efficient.

This revenue fee is the operational cost of parking at the Department of Transportation Agency of Temanggung Regency. 75 percent of the operational costs are for the 
maintenance of parking facilities, printing parking tickets, making KTA, making uniforms, buying parking attendant equipment, and another 25 percent is the operational costs used by revenue collectors. Revenue collectors also supervise or socialize directly with the parking attendant. Besides reaching out to parking attendants, through revenue collector the Department of Transportation also socializes with shop owners who do not yet have parking attendants. However, the socialization was not that easy, because many shop owners objected to the idea thinking that if there were parking attendants, there will be not so many customers. Even though the purpose of the parking attendant is for public order and convenience for consumers, such as a parked vehicle is arranged.

\section{Conclusion}

The conclusions that can be drawn from this research are (1) Roadside Parking Space Retribution had a significant impact on Local Own-source Revenue in Temanggung Regency (2) Roadside Parking Space Retribution had more potential if it is explored more optimally to increase the Original Regional Revenue of Temanggung Regency (3) The forecasting for the next 3 periods showed that the roadside parking space retribution had a downward trend. This decrease occurred because of the history of the previous months, namely if from January to November the parking attendant who made not many deposits and only paid off the deposit target in December, so that it would form a graph that increased dramatically in that month (4) The effectiveness ratio of the revenue of Roadside Parking Space Retribution for the last 4 years is included in the category very effective, while the efficiency ratio is very efficient. This is because when viewed on an annual basis, the revenue from the roadside parking space retribution always meets the target, which is paid off every December.

\section{REFERENCES}

Act Number 23 of 2014 On Local Government (p. 460). (2014).

Act Number 32 of 2004 On Local Government (p. 249). (2004).

http://www.dpr.go.id/dokjdih/document/uu/33.pdf

Act Number 33 of 2004 on Financial Balance Between Central and Local Governments (p. 39). (2004).

BPS. (2020). Statistik Keuangan Pemerintah Provinsi 2017-2020.

Dirjen Perhubungan Darat. (1996). Pedoman Teknis Penyelenggaraan Fasilitas Parkir. In Jurnal Fondasi (Vol. 1, Issue 1, pp. 1-41).

Erlangga, L. T., \& Darsyah, M. Y. (2018). Peramalan Harga Cabai Rawit Merah di Jakarta Pusat Mengunakan Metode Moving Average dan Single Exponential Smoothing. Prosiding Seminar Nasional Mahasiswa Unimus, 1, 396-399.

Hartoyo, N. (2014). Optimalisasi PAD untuk Peningkatan Kinerja Pemda. Widyaiswara Balai Diklat Malang.

https://bppk.kemenkeu.go.id/content/berita/balai-diklat-keuangan-malang-optimalisasipad-untuk-peningkatan-kinerja-pemda-2019-11-05-ed30578d/ 
Hasan, A. R., \& Suratman. (2013). An Analysis of the Implementation of Parking Management Policies in Increasing the Regional Income of Makassar City. IOSR Journal of Humanities And Social Science, 13(3), 01-06. https://doi.org/10.9790/0837-1330106

Hasita, I. N. (2006). Analisis Pendapatan Retribusi Pasar Kota Magelang Tahun 2001-2004. Universitas Gadjah Mada.

Hawati, T. M., Oktaviani, R., \& Falatehan, A. F. (2017). Strategi Optimalisasi Penerimaan Retribusi Pelayanan Parkir Tepi Jalan Umum Kota Tangerang Selatan. Jurnal Penelitian Transportasi Darat, 19(1), 49-70. https://doi.org/10.25104/jptd.v19i1.605

Jufrizen. (2013). Analisis Potensi Penerimanaan Retribusi Parkir Pada Pusat - Pusat Perbelanjaan Kota Medan. Jurnal Manajemen \& Bisnis, 13(1), 30-45, ISSN 1693-7619.

Kartika, A. A. G., Mochtar, I. B., \& Widyastuti, H. (2016). Konsep Pemodelan Durasi dan Volume Parkir untuk Berbagai Tata Guna Lahan di Kota Surabaya. IPTEK Journal of Proceedings Series, 3(5), 25-34. https://doi.org/10.12962/j23546026.y2017i5.3111

Kurniawan, T. (2005). Determinan Tingkat Suku Bunga Pinjaman Di Indonesia Tahun 1983 - 2002. Buletin Ekonomi Moneter Dan Perbankan, 7(3), 437-460.

Mahmudi. (2019). Analisis Laporan Keuangan Pemerintah Daerah. UPP STIM YKPN.

Malombeke, N. (2016). Analisis Potensi Dan Efektivitas Pemungutan Pajak Parkir Di Kabupaten Minahasa Utara Analysis of the Potential and Effectiviness of Parking Tax Collection in North Minahasa Regency. Maret, 4(1), 645-655.

Puspitasari, E. R. A., \& Rohman, A. (2014). Analisis Efektivitas, Efisiensi, Dan Kontribusi Pajak Daerah Dan Retribusi Daerah Terhadap Peningkatan Pad Kabupaten Blora Tahun 2009-2013. Diponegoro Journal of Accounting, 3(4), 133-147.

Putra, G. E. S. (2016). Efektivitas Penerimaan Retribusi Parkir Pada Dinas Pendapatan Daerah (DISPENDA) Kabupaten Buleleng Periode Tahun 2010-2015. Jurnal Program Studi Pendidikan Ekonomi (JPPE), 7(2).

https://ejournal.undiksha.ac.id/index.php/JJPE/article/view/7753

Religia, D., \& Pratomo, D. (2014). Analisis Pengaruh Efektivitas Pajak dan Retribusi Parkir Terhadap Efektivitas Pendapatan Asli Daerah Kota Bandung Tahun 2011 Sampai 2013. E-Proceeding of Management, 1(3), 158-169.

https://core.ac.uk/download/pdf/299876739.pdf

Ritonga, I. T., Suhartono, E., Aunurrohman, C., \& Haza, Z. F. (2017). Metoda Penghitungan Potensi PAD. Pustaka Pelajar.

Saad, S. R., Yamin Jinca, M., \& Asdar, M. (2017). Arrangement of the Street Parking at the Pomalaa Market of Kolaka Regency. International Journal of Engineering Inventions, 6(5), 2278-7461. www.ijeijournal.com

Saputra, P. P., \& Safitri, R. (2020). Implementasi Kebijakan Retribusi Parkir di Tepi Jalan Umum Kota Pangkalpinang. JSHP : Jurnal Sosial Humaniora Dan Pendidikan, 4(2), $40-$ 46. https://doi.org/10.32487/jshp.v4i2.841

Soejanto, I., Berlianty, I., \& Astanti, Y. D. (2018). Monte Carlo Simulation of on-Street Parking Retribution Revenue Potential in Sleman Regency Indonesia. International Journal of Engineering \& Technology, 7(3.30), 357. https://doi.org/10.14419/ijet.v7i3.30.18333

Sriparno, A. R., \& Sari, M. M. R. (2015). Analisis Pajak Dan Retribusi Daerah Pada Tingkat Efektivitas Dan Kemandirian Keuangan Daerah. E-Jurnal Akuntansi, 13(2), 368-386.

Widarjono, A. (2005). Ekonometrika: Teori dan Aplikasi. Ekonisia FE UII. 